\title{
INFLUENCE OF EDDY COVARIANCE SENSOR HEIGHT ABOVE THE OIL PALM CANOPY ON $\mathrm{CO}_{2}$ AND ENERGY FLUXES
}

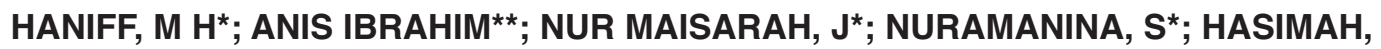 \\ $M^{\star} ;$ AFIFAH, A $^{\star}$ and YUSUP, $Y^{\star *}$
}

\begin{abstract}
A study was carried out to determine the influence of eddy covariance (EC) sensor placement above the oil palm canopy on footprint, $\mathrm{CO}_{2}$, and energy fluxes. The study was carried out on 18-year old oil palms planted on mineral soil at an inland location in Peninsular Malaysia. Measurements were done from July to September 2016. The open path $\mathrm{CO}_{2} / \mathrm{H}_{2} \mathrm{O}$ analyser and 3-D sonic anemometer were initially installed at $30 \mathrm{~m}$ height. Both sensors were later repositioned at $19 \mathrm{~m}$ height on 2 August 2016. The different sensor heights had a significant effect on the diurnal $\mathrm{CO}_{2}$ fluxes above the oil palm canopy. The average $\mathrm{CO}_{2}$ flux measured was about $-3.77 \mu \mathrm{mol} \mathrm{CO} \mathrm{Cm}^{-2} \mathrm{~s}^{-1}$ at $30 \mathrm{~m}$ and was reduced to $-0.75 \mu \mathrm{mol} \mathrm{CO} 2 \mathrm{~m}^{-2} \mathrm{~s}^{-1}$ at $19 \mathrm{~m}$ height. Lowering the sensor height also reduced the $\mathrm{CO}_{2}$ flux footprint by about $40 \%$ to a distance of $584 \mathrm{~m}$. The energy imbalance is evident at the two different sensor heights and needs to be further studied.
\end{abstract}

\section{Keywords: oil palm, eddy covariance, energy balance, $\mathrm{CO}_{2}$ fluxes.}

Date received: 26 July 2017; Sent for revision: 28 July 2017; Received in final form: 24 November 2017; Accepted: 23 January 2018.

\section{INTRODUCTION}

In 2016, Malaysia produces about 17.3 million tonnes of crude palm oil, which accounts for about $29.4 \%$ of the world palm oil production (MPOB, 2017; Oil World, 2016; Global Palm Oil Production, 2017). The oil palm plantation with its perennial green cover and closed canopy shows the main features of a tropical rainforest. It was reported that the oil palm plantation produces $44.0 \mathrm{t}$ of dry matter per hectare per year as compared to $25.7 \mathrm{t}$ of dry matter per hectare per year produced by the tropical rainforest (Sunaryathy et al., 2015; Asari et al., 2013; Khalid et al., 1999; Henson, 1999). The oil palm dry matter production was reported to remain high

\footnotetext{
* Malaysian Palm Oil Board,

6 Persiaran Institusi, Bandar Baru Bangi,

43000 Kajang, Selangor, Malaysia.

E-mail: mhaniffharun@gmail.com

** Environmental Technology, School of Industrial Technology, Universiti Sains Malaysia,

11800 Minden, Pulau Pinang, Malaysia.
}

throughout their whole 25-year economic life cycle. In Malaysia, the total area planted with oil palm in 2016 was about 5.7 million hectares (MPOB, 2017).

There are very few researches done on carbon flux and its variations in the oil palm ecosystems in Malaysia. Carbon exchange between oil palm ecosystems and the atmosphere could vary both seasonally and interannually even at the same location, let alone among different locations. Therefore, further information on the state of carbon sequestration and seasonal fluctuation is beneficial, not only to understand the role of oil palm plantations in the worldwide carbon cycles and predicting future carbon exchanges under climate change but also for developing policies or management practices to mitigate oil palms against climate change.

The eddy covariance (EC) technique is commonly used to measure surface gaseous and energy fluxes. It is an important technique for measuring and calculating the vertical fluxes within the atmospheric boundary layer (Baldocchi et al., 
2001; 1988). The EC method assumes that the transfer of energy and gases adjacent to the land surface within the boundary layer is entirely turbulent. The method examines high-frequency wind and scalar atmospheric data series and produces values of fluxes of these properties. This statistical method is widely used in meteorology and other applications for determining the exchange rates of trace gases over natural ecosystems and agricultural fields and quantifying gas emissions rates from land and water areas. It is frequently used to estimate energy, heat, water vapour, $\mathrm{CO}_{2}$ and methane fluxes (Burba, 2013; Foken, 2008a; Baldocchi et al., 1988). The method also provides the average flux over its footprint in the upwind direction, approximately 100 times the instrument height above the zeroplane displacement height or two-thirds of the plant canopy height. This is a general guide used to determine the suitable height for installing the EC sensors based on available fetch to be measured.

EC measurements require very fast and precise instruments because of the fast vertical movement of the wind and the trace amounts of gas (such as $\mathrm{CO}_{2}, \mathrm{H}_{2} \mathrm{O}$, and $\mathrm{CH}_{2}$ ) carried by the upward and downward wind. The basic EC instruments include a $\mathrm{CO}_{2} / \mathrm{H}_{2} \mathrm{O}$ analyser (open path) and a sonic anemometer (Burba, 2013; Aubinet et al., 2012; Burba and Anderson, 2007). Sensor location and separation are important factors that could affect optimal sampling. The suggested horizontal separation between the sonic anemometer and gas analysers is between 20 and $30 \mathrm{~cm}$ to ensure measurement of the same air parcels. The sensors position should not be so close together such that the $\mathrm{CO}_{2}$ gas analyser will not distort airflow through the sonic anemometer. Also, the $\mathrm{CO}_{2}$ gas analyser should not be positioned such that it blocks or distorts vertical airflow through the sonic anemometer sample volume. Particularly when they are installed close to the plant canopy, the vertical separation should be minimised. However, it is acceptable when the sensors are installed quite high above the plant canopy. Both sensors are generally recommended to be positioned at a minimum height of at least 2 $\mathrm{m}$ above the canopy of vegetation being studied (Burba and Anderson, 2007).

This study was carried out to determine the effects of EC sensor height above the oil palm canopy on flux footprint, $\mathrm{CO}_{2}$, and energy fluxes.

\section{MATERIALS AND METHOD}

\section{Site Description}

The study was carried out on 18-year old oil palms planted on mineral soil at an inland location in Peninsular Malaysia (latitude $2^{\circ} 47^{\prime} 20^{\prime \prime} \mathrm{N}, 102^{\circ} 55^{\prime} 58^{\prime \prime}$ E) situated in Keratong, Pahang, Malaysia. A total area of 135 ha was planted in 1998 with commercial DxP palms at a planting density of 148 palms ha-1. The soil is sandy clay of Rengam series (typic Paleudults, USDA Classification) and Holyrood series (typic Kandiudults, USDA Classification) with a gently undulating terrain. This study site has an annual average air temperature of $26.6^{\circ} \mathrm{C}$, average annual rainfall of $916.94 \mathrm{~mm}$ and average daily net radiation of $114.53 \mathrm{~W} \mathrm{~m}^{-2}$.

\section{EC Measurements}

A $30 \mathrm{~m}$ tall EC tower was installed in the plantation to allow the measurements to be taken from a homogenous area of oil palms. The standard EC technique was used for measuring $\mathrm{CO}_{2}$ fluxes, comprising of an ultrasonic anemometer (CSAT3 CSI, USA) and infrared gas analyser (LI-7500, LI-COR, USA) operating at $10 \mathrm{~Hz}$ sampling rate (Aubinet et al., 2000; Baldocchi et al., 1988). The design of the tower and EC equipment were described by Haniff et al. (2016).

Measurements were done during the period of July to September 2016. The open path $\mathrm{CO}_{2} / \mathrm{H}_{2} \mathrm{O}$ analyser and 3-D sonic anemometer were initially installed at a height of $30 \mathrm{~m}$. After about one month, the sensors were repositioned at a lower height of 19 m on 2 August 2016. The average canopy height of the 18-year old palm was about $17 \mathrm{~m}$ (i.e. from the tip of the unopen spear leaf to the ground surface).

Data collected for about one month at each $19 \mathrm{~m}$ and $30 \mathrm{~m}$ were then processed using the EddyPro flux computation software (LI-COR, USA) to compute gases and energy fluxes. Processing EC data involves many steps, such as despiking, coordinate rotation, time lag determination, density correction, frequency response correction, and other QA/QC operations. Spike count or removal was done according to the procedure by Mauder et al. (2013). While statistical tests for raw time series data such as Amplitude resolution, Dropouts, Absolute limits, Skewness and kurtosis, Discontinuities and Time lags were done according to the method by Vickers and Mahrt (1997).

Gap filling was performed for $30 \mathrm{~min}$ fluxes for all data points. The total of half-hourly data was 14139 data points and 731 data points for daily average. The filtration was based on 30 min fluxes, and then the daily means were calculated. The halfhourly measurements of EC and climatological data were then used to assess $\mathrm{CO}_{2}$ fluxes, surface energy partitioning, and closure.

The $\mathrm{EC} \mathrm{CO}_{2}$ flux footprint at the two different sensor heights was analysed using the models by Kljun et al. (2004) and Kormann and Meixner (2001). Spatial distributions of footprint source areas were evaluated to reveal the relative flux contribution to the total flux over the observation period. 


\section{Energy Balance Analysis}

The energy balance closure (EBC) was carried out by comparing the sum of sensible heat $(\mathrm{H})$ and latent heat flux (LE) and the difference between net radiation $(\mathrm{Rn})$, ground heat $(\mathrm{G})$ and energy storage (S) (Wilson et al., 2002; Culf et al., 2004; Foken, 2008b). The ideal closure is achieved when the intercept is zero and slope and the coefficient of determination are one.

The energy balance ratio (EBR) is the ratio of the sum of turbulent fluxes ( $\mathrm{H}$ and $\mathrm{LE}$ ) to the available energy. EBR gives an overall evaluation of energy balance closure at longer time scales by averaging over random errors in the half-hour measurements and the ideal closure is 1 . It has the potential to neglect biases in the half-hourly data, such as the tendency to overestimate positive fluxes during the day and underestimate negative fluxes at night.

\section{RESULTS AND DISCUSSIONS}

Data obtained from the two different sensor heights above the oil palm canopy were analysed for $\mathrm{H}$, LE, and carbon dioxide fluxes and $\mathrm{CO}_{2}$ flux footprint.

\section{$\mathrm{CO}_{2}$ Flux}

The diurnal $\mathrm{CO}_{2}$ fluxes above the oil palm canopy at $30 \mathrm{~m}$ and $19 \mathrm{~m}$ heights is shown in Figure 1. The graph shows the day and night behaviour of $\mathrm{CO}_{2}$ fluxes before and after sensor reposition. Average $\mathrm{CO}_{2}$ flux measured was about $-3.77 \mu \mathrm{mol}$ $\mathrm{CO}_{2} \mathrm{~m}^{-2} \mathrm{~s}^{-1}$ and $-0.75 \mu \mathrm{mol} \mathrm{CO} \mathrm{CO}^{-2} \mathrm{~s}^{-1}$ at $30 \mathrm{~m}$ and
$19 \mathrm{~m}$ heights, respectively. They were significantly different at $p \leq 0.001$ between the two heights. The average value of $\mathrm{CO}_{2}$ flux for the duration shown in Figure 2 was $-0.64 \mu \mathrm{mol} \mathrm{CO} \mathrm{Cm}^{-2} \mathrm{~s}^{-1}$ and its minimum and maximum were -38.2 and $39.9 \mu \mathrm{mol} \mathrm{CO}_{2} \mathrm{~m}^{-2} \mathrm{~s}^{-1}$, respectively.

Table 1 shows the values of diurnal plots, meteorological variables and filtration process that compare both $30 \mathrm{~m}$ and $19 \mathrm{~m}$ heights study. The percentage of 30 min flux data removed or

TABLE 1. THE VALUES OF DIURNAL PLOTS, METEOROLOGICAL VARIABLES AND FILTRATION PROCESS THAT COMPARE BOTH $30 \mathrm{~m}$ AND $19 \mathrm{~m}$ SENSOR HEIGHTS STUDY

\begin{tabular}{lrr}
\hline & $30 \mathbf{~ m}$ & \multicolumn{1}{c}{$\mathbf{1 9} \mathbf{~ m}$} \\
\hline Diurnal Plot of $\mathrm{CO}_{2}$ Fluxes: & & \\
Min & -21.780 & -11.0900 \\
Max & 10.140 & 3.7340 \\
Average & $-3.77 \mathrm{a}$ & $-0.75 \mathrm{~b}$ \\
Meteorological Variables: & & \\
Air temperature $\left({ }^{\circ} \mathrm{C}\right)$ & $26.50 \mathrm{a}$ & $27.02 \mathrm{a}$ \\
Wind speed $\left(\mathrm{m} \mathrm{s}^{-1}\right)$ & $1.81 \mathrm{a}$ & $0.99 \mathrm{~b}$ \\
Relative humidity $(\%)$ & $83.55 \mathrm{a}$ & $83.29 \mathrm{a}$ \\
Solar radiation $\left(\mathrm{W} \mathrm{m}{ }^{-2}\right)$ & $146.29 \mathrm{a}$ & $124.52 \mathrm{a}$ \\
Rainfall $(\mathrm{mm})$ & $223 \mathrm{a}$ & $693 \mathrm{~b}$ \\
*Filtration $(\%):$ & & \\
LE & $26.5 \mathrm{a}$ & $35.2 \mathrm{~b}$ \\
$\mathrm{H}$ & $23.7 \mathrm{a}$ & $36.8 \mathrm{~b}$ \\
$\mathrm{CO}_{2}$ & $23.3 \mathrm{a}$ & $36.6 \mathrm{~b}$ \\
\hline
\end{tabular}

Note: Average $\mathrm{CO}_{2}$ flux values followed by the same alphabet are not significantly different at $\mathrm{p}<0.05$.

Source: *Foken et al. (2004).

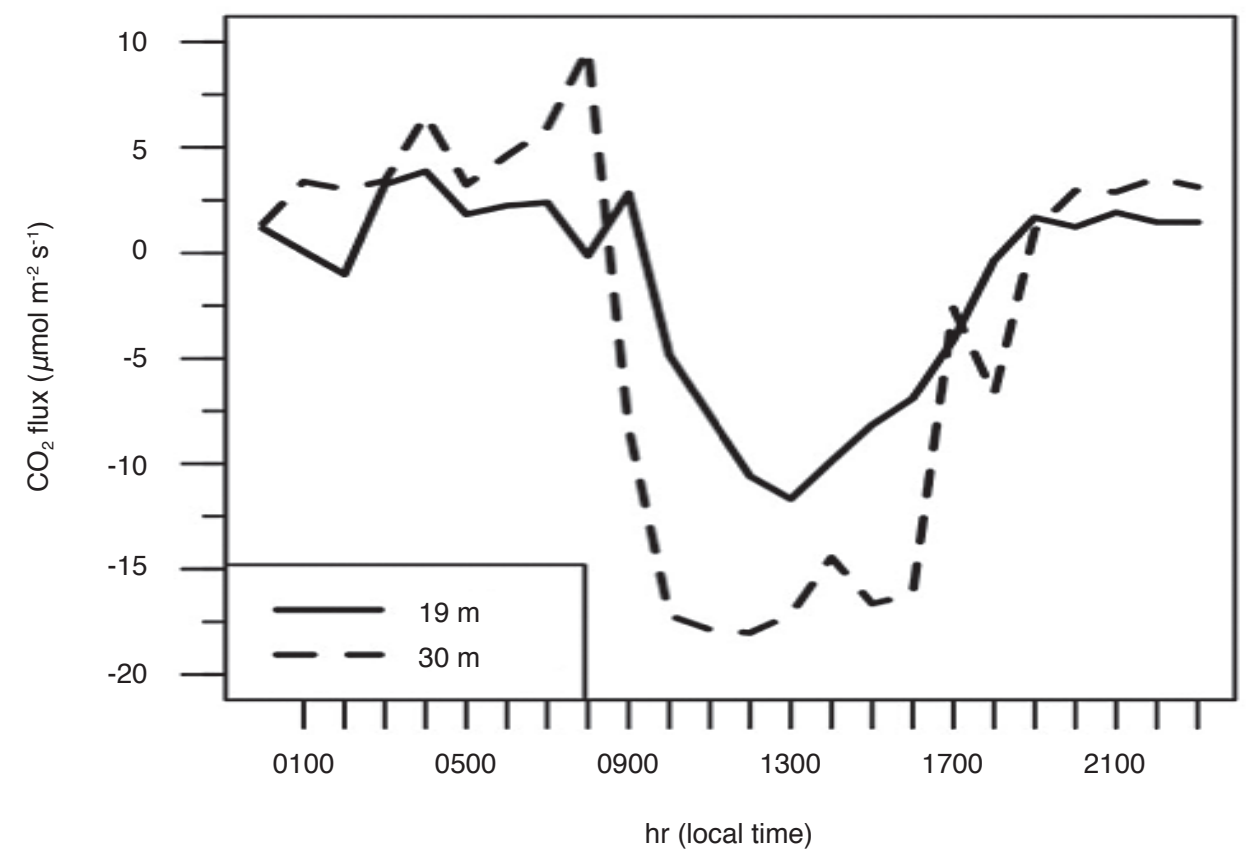

Figure 1. The diurnal variations of $\mathrm{CO}_{2}$ fluxes at two different sensor heights. 


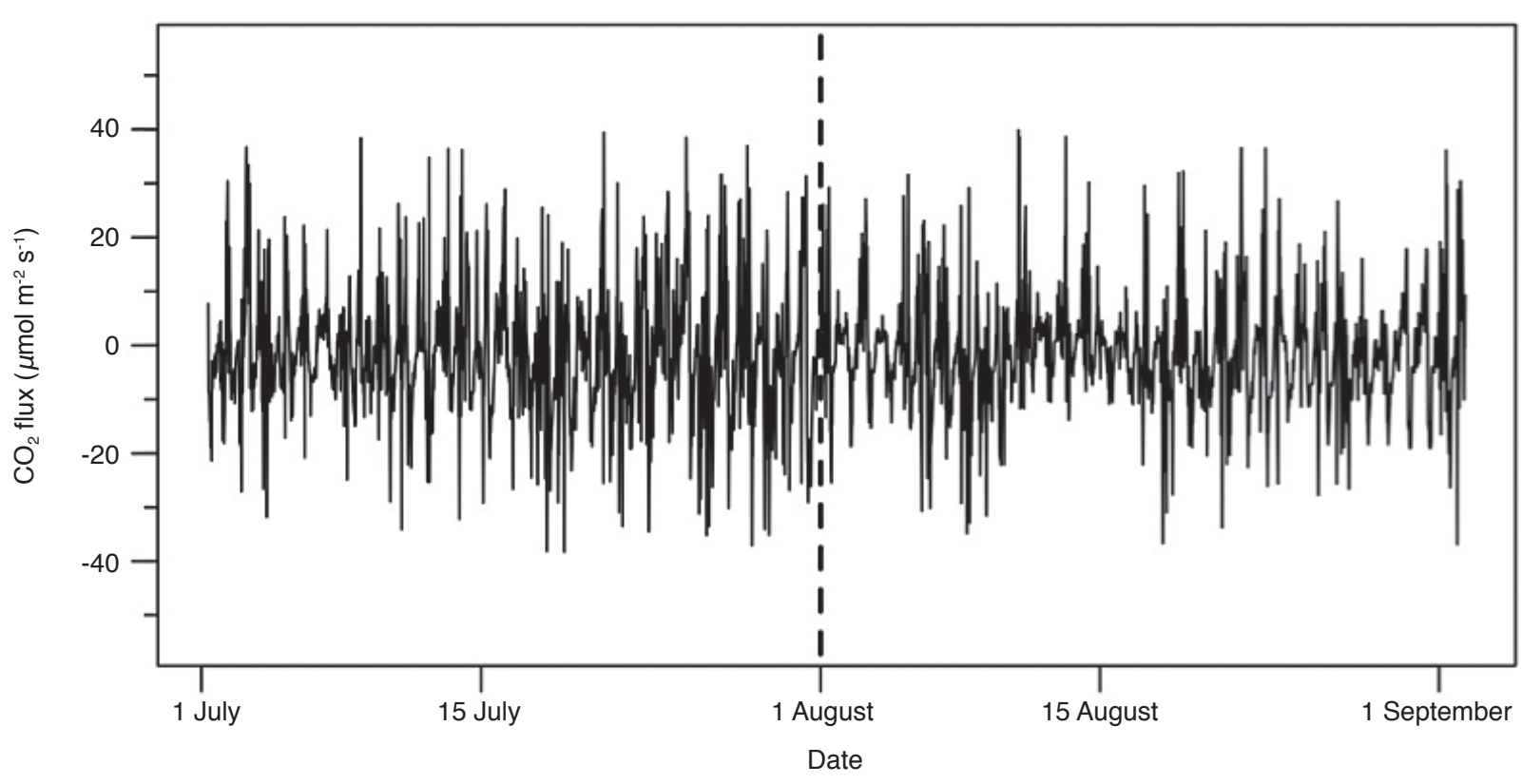

Figure 2. Half-hourly $\mathrm{CO}_{2}$ fluxes above the 18-year old oil palm canopy with day of year (DOY); the dotted line represents the repositioning (2 August 2016) of the eddy covariance sensor from the height of $30 \mathrm{~m}$ to $19 \mathrm{~m}$.

TABLE 2. THE PERCENTAGE OF 30 min FLUX DATA REMOVED OR LOST OVER THE ENTIRE STUDY PERIOD

\begin{tabular}{lc}
\hline & Filtered data points (\%) \\
\hline${ }^{*} \mathrm{CO}_{2}$ & $266(9.5 \%)$ \\
$\mathrm{LE}$ & $143(5.8 \%)$ \\
$\mathrm{H}$ & $60(2.1 \%)$ \\
Meteorological variables & $145(5.2 \%)$ \\
(rain,T,RH,RN,WS,WD) & \\
Total data lost & $614(21 \%)$ \\
\hline
\end{tabular}

Note: $\mathrm{T}$ - air temperature $\left({ }^{\circ} \mathrm{C}\right)$.

$\mathrm{RN}$ - net radiation $\left(\mathrm{W} \mathrm{m}^{-2}\right)$.

WD - wind direction $\left({ }^{\circ}\right)$

RH - relative humidity (\%).

WS - wind speed $\left(\mathrm{m} \mathrm{s}^{-1}\right)$.

Source: * Foken et al. (2004).

lost over the entire study period is shown in Table 2. Approximately $21 \%$ of the total half-hourly data records were lost after the filtration process.

Previously, it was reported that the monthly averaged $\mathrm{CO}_{2}$ flux values ranged between -2 to -6 $\mu \mathrm{mol} \mathrm{m} \mathrm{m}^{-2} \mathrm{~s}^{-1}$, with an average value of about -3.5 $\mu \mathrm{mol} \mathrm{CO} \mathrm{CO}^{-2} \mathrm{~s}^{-1}$ (Haniff et al., 2016). This variation could be caused by the irregular cumulative monthly precipitation and net radiation observed at the study site.

\section{$\mathrm{CO}_{2}$ Flux Footprint}

Figure 3 shows the average $\mathrm{CO}_{2}$ flux footprint at the two different sensor heights. The average footprint was about $975 \mathrm{~m}$ when sensor height was at $30 \mathrm{~m}$. However, the average footprint was decreased by as much as $40 \%$ to $584 \mathrm{~m}$ when sensor height was reduced to $19 \mathrm{~m}$. These responses were expected since three main factors that could influence the flux footprint are EC sensor height, surface roughness, and atmospheric thermal stability. The increase in EC sensor height, decrease in surface roughness, and stable atmospheric condition would produce an increase in the footprint size and change the peak contribution further away from the instrument. Similarly, a reduction in EC sensor height, increase in surface roughness, and unstable atmospheric condition would produce a reduction in the footprint size and change the peak contribution closer to the instrument. It should be noted that footprint locations can be overestimated or biased due to difficulty in modelling the contribution of flux sources under very stable conditions (Aubinet et al., 2012). Furthermore, the $\mathrm{CO}_{2}$ and energy fluxes above an oil palm plantation were clearly influenced by meteorological trends (Haniff et al., 2016; 2014; Henson and Haniff, 2005; 2004).

\section{EBC}

EBC was estimated by using linear regression of turbulent energy fluxes [i.e. sensible $(\mathrm{H})$ and latent heat (LE)] against available energy [i.e. net radiation $\left(R_{n}\right)$, less the energy stored (S)]. Figure 4 shows that the EBC value was significantly higher at sensor height of $30 \mathrm{~m}$ compared to $19 \mathrm{~m}$. The slope was less than 1 for the two different sensor heights, ranging from 0.57 at sensor height of $30 \mathrm{~m}$ and 0.51 at sensor height of $19 \mathrm{~m}$, with an average value of 0.54 . The average coefficient of determination $\left(R^{2}\right)$ was 0.78 , ranging from 0.75 at $19 \mathrm{~m}$ to 0.80 at $30 \mathrm{~m}$ height. The ideal closure is represented by an intercept of zero and slope of 1 (Wilson et al., 2002). Therefore, the energy balance from this EC flux dataset was not closed. 

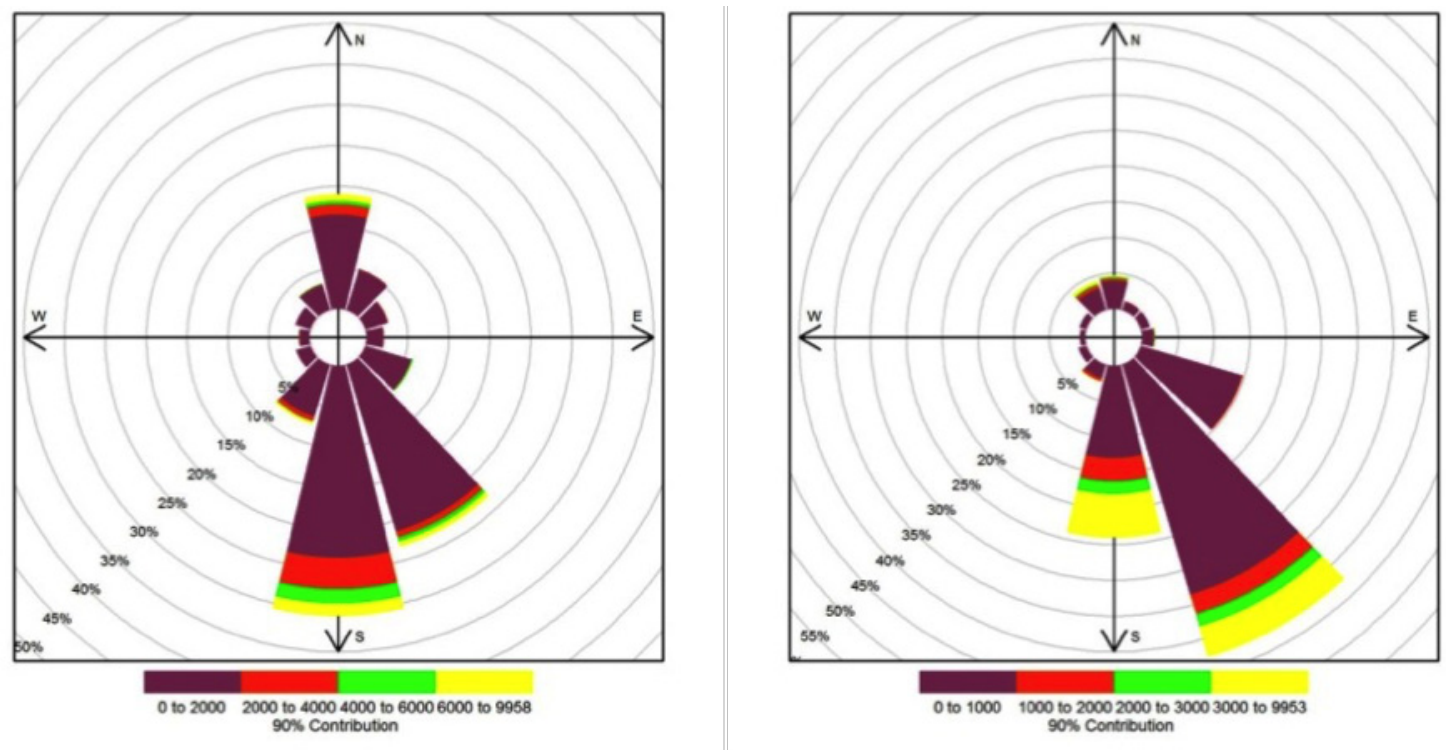

Figure 3. Average $90 \%$ flux footprint $(m)$ of $\mathrm{CO}_{2}$ for different wind directions and percentages of occurrences (denoted by circles) obtained at eddy covariance sensor heights of (a) $30 \mathrm{~m}$, and (b) at $19 \mathrm{~m}$.
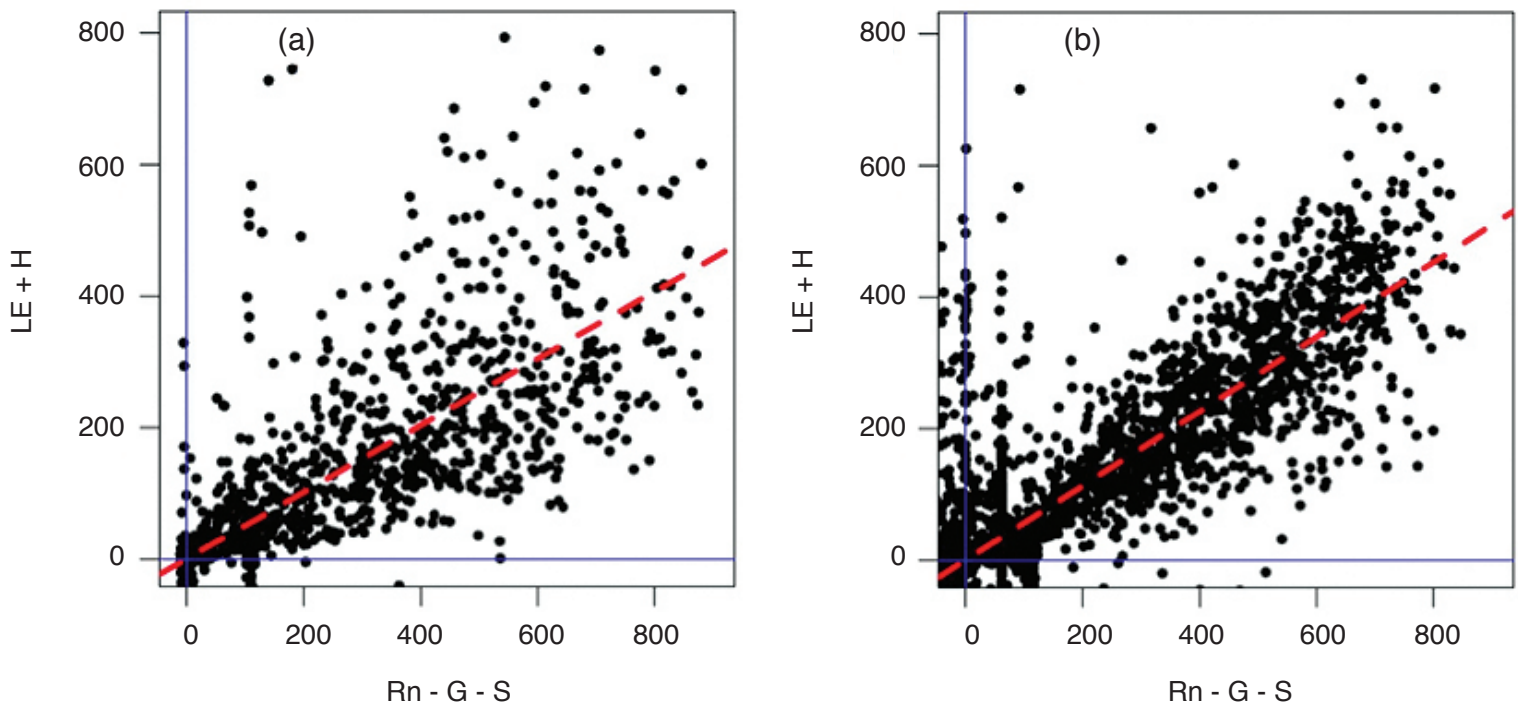

Figure 4. Energy balance closure (EBC) analyses for eddy covariance sensor heights at (a) $19 \mathrm{~m}$ (b) 30 m; dashed lines represent linear regression lines and the details are given in Table 3 .

Usually, the sum of LE and $\mathrm{H}$ heat exchange measured by the EC method will often underestimate the available energy by about $10 \%-40 \%$ (Stoy et al., 2013). The energy balance requires that the available energy at the surface (i.e. the difference between net radiation and ground heat flux) is equivalent to the sum of sensible heat and latent heat flux. However, when the energy balance components are measured separately, a perfect balance is seldom obtained but can be reasonably close if the measurements have been well conducted. Hence, EBC can be used to examine the reliability and quality of EC dataset. A dataset with EBC value within $10 \%$ is considered quite reliable (Culf et al., 2004).
The energy imbalance was still apparent at the two different sensor heights as shown by the EBR value obtained from the ratio of turbulent energy flux to available energy for the duration of the measurement period. Table 3 shows that the EBR values at the two different EC sensor heights. The EBR value at sensor height of $19 \mathrm{~m}$ was $7 \%$ greater than at sensor height of $30 \mathrm{~m}$. Average EBR obtained for the two different sensor heights was about 0.58 .

The analysis of EBC assumes that the energy in the system can be estimated from the five measured components (i.e. LE, H, Rn, G, and S) and that all energy stored underneath the sensor ( $G$ and $S$ ) is properly measured. However, several factors could 
be associated with the failure to match the EC flux footprint with the source area of Rn, G, and S. The issues involved in matching scales of observations were discussed in detail by Schmid (1997), mainly on the difference between net radiometers and flux footprints. The source area radius for a net radiometer is related to sensor height and is centred below the radiation sensor. Usually, the instrument protrudes horizontally off a tower, and often the sensor may be influenced by the tower structure or removal of vegetation near the tower. The spatial dimension of the flux footprint is often not secure in space and significantly influenced by atmospheric conditions. Theoretically, the source areas for a net radiometer and EC flux footprint are difficult to match. For example, the estimation of $S$ in tall vegetation is quite difficult because it involves sampling of biomass temperatures, such as depth of woody tissue and canopy height. Moreover, measurements of net radiation do not reflect the radiative energy available for the conductive and convective heat exchange from the complex landscape (Wohlfahrt et al., 2016; Stoy et al., 2013).

\begin{tabular}{|c|c|c|}
\hline & $19 \mathrm{~m}$ & $30 \mathrm{~m}$ \\
\hline slope & 0.51 & 0.57 \\
\hline $\mathrm{R}^{2}$ & 0.75 & 0.80 \\
\hline \multicolumn{3}{|c|}{ p-value } \\
\hline EBR & $2.2 \mathrm{e}-16$ & 2.2e-16 \\
\hline 0.56 & $2.2 \mathrm{e}-16$ & 0.60 \\
\hline 0.60 & & \\
\hline
\end{tabular}

Note: EBR - energy balance ratio.

\section{CONCLUSION}

In this article, we presented the effects of EC sensor height above the oil palm canopy on $\mathrm{CO}_{2}$ and energy fluxes. Different sensor heights affected the $\mathrm{CO}_{2}$ fluxes above the oil palm canopy. Lowering the sensor height tend to reduce the $\mathrm{CO}_{2}$ flux footprint, EBC and EBR values. It is important to have the sensor height lowered in order to reduce the contamination of $\mathrm{CO}_{2}$ fluxes other than from the oil palm area. However, there is an increased risk of placing sensors within the canopy roughness layer that could affect the accuracy of flux measurements. The energy imbalance is quite apparent at the two different sensor heights. Further study is needed to understand the failure to match the EC energy flux footprint.

\section{ACKNOWLEDGEMENT}

The authors thank the Director-General of MPOB for permission to publish this article.

\section{REFERENCES}

AUBINET, M; GRELLE, A; IBROM, A; RANNIK, Ü; MONCRIEFF, J; FOKEN, T; KOWALSKI, A S; MARTIN, P H; BERBIGIER, P; BERNHOFER, C H; CLEMENT, R; ELBERS, J; GRANIER, A; GRÜNWARLD, T; MORGENSTERN, K; PILEGAARD, K; REBMANN, C; SNIJDERS, W; VALENTINI, R and VESALA, T (2000). Estimates of the annual net carbon and water exchange of forest: The EUROFLUX methodology. Adv. Ecol. Res., 30: 113-175.

AUBINET, M; VESALA, T and PAPALE, D (2012). Eddy Covariance: A Practical Guide to Measurement and Data Analysis. Springer Atmospheric Sciences, Springer Verlag. 438 pp.

ASARI, N; SURATMAN, M N; JAAFAR, J and KHALID, M M (2013). Estimation of aboveground biomass for oil palm plantations using allometric equations. IPCBEE 2013: Proc. of the $4^{\text {th }}$ International Conference on Biology, Environment and Chemistry. p. 110-114.

BALDOCCHI, D D; HICKS, B B and MEYERS, T P (1988). Measuring biosphere-atmosphere exchanges of biologically related gases with micrometeorological methods. Ecology, 69: 13311340.

BALDOCCHI, D D; FALGE, E and GU, L (2001). FLUXNET: A new tool to study the temporal and spatial vari-ability of ecosystem-scale carbon dioxide, water vapour and energy flux densities. Bull. Am. Meteor. Soc., 82: 2415-2434.

BURBA, G and ANDERSON, D (2007). Introduction to the Eddy Covariance Method: General Guidelines and Conventional Workflow. LI-COR Biosciences, Lincoln, USA. Electronic edition. 141 pp.

BURBA, G (2013). Eddy Covariance Method for Scientific, Industrial, Agricultural and Regulatory Applications: A Field Book on Measuring Ecosystem Gas Exchangeand Areal Emission Rates. LI-COR Biosciences, Lincoln, USA. 331 pp.

CULF, A D; FOKEN, T and GASH, J H C (2004). The energy balance closure problem. Vegetation, Water, Humans and the Climate (Kabat, P; Claussen, M; Whitlock, S; Gash, J H; Guenni, L B d; Meybeck, M; Pielke, R; Vörösmarty, C J; Hutjes, R W and Lütkemeier, $S$ eds.). Springer, Berlin. p. 59-166.

FOKEN, T; GOCKEDE, M; MAUDER, M; MAHRT, L; AMIRO, B D and MUNGER, J W (2004). Post-field data quality control. Handbook of Micrometeorology: A Guide for Surface Flux Measurements (Lee, X ed.). Kluwer, Dordrecht. p. 81-108. 
FOKEN, T (2008a). Micrometeorology. SpringerVerlag, Berlin, Germany. 308 pp.

FOKEN, T (2008b). The energy balance closure problem: An overview. Ecol. Appl., 18: 1351-1367.

GLOBAL PALM OIL PRODUCTION (2017). Global palm oil production 2016/2017. http://www. globalpalmoilproduction.com/previous-year.asp

HANIFF, M H; ANIS IBRAHIM, NUR MAISARAH JANTAN; NURAMANINA SHAHABUDIN; HASIMAH MOS and YUSRI YUSUP (2016). Carbon dioxide and energy fluxes above an oil palm canopy in Peninsular Malaysia. International J. Agronomy and Agricultural Research (IJAAR) Res. Vol. 9(2): 137-146.

HANIFF, M H; HENSON, I E and MD NOOR, M $\mathrm{R}$ (2004). Continuous measurement of canopy $\mathrm{CO}_{2}$ and $\mathrm{H}_{2} \mathrm{O}$ fluxes of an oil palm plantation using eddy correlation technique. Paper presented at the $15^{\text {th }}$ Malaysian Society of Plant Physiology Conference Advances in Plant Science.

HENSON, I E (1999). Comparative ecophysiology of oil palm and tropical rainforest. Oil Palm and the Environment: A Malaysian Perspective (Gurmit Singh et al., eds.). Malaysian Oil Palm Growers Council, Kuala Lumpur. p. 9-39.

HENSON, I E and HANIFF, M H (2005). The influence of climatic conditions on gas and energy exchanges above a young oil palm stand in North Kedah, Malaysia. J. Oil Palm Res. Vol. 17: 73-91.

KHALID, H; ZIN, Z Z and ANDERSON, J M (1999). Quantification of oil palm biomass and nutrient value in a mature plantation. I. Above-ground biomass. J. Oil Palm Res. Vol. 2: 23-32.

KLJUN, N; CALANCA, P; ROTACH, M W and SCHMID, H P (2004). A simple parameterisation for flux footprint predictions. Boundary-layer Meteorology, 112(3): 503-523.

KORMANN, $\mathrm{R}$ and MEIXNER, F (2001). An analytical footprint model for non-neutral stratification. Boundary-layer Meteorology, 99(2): 207224.

MAUDER, M M; CUNTZ, C; DRÜE, A; GRAF, C; REBMANN, H P; SCHMID, $M$ and STEINBRECHER, R (2013): A strategy for quality and uncertainty assessment of long-term eddycovariance measurements. Agric. For. Meteor., 169: 122-135.

MPOB (2017). Malaysian Oil Palm Statistics 2016. MPOB, Bangi.

OIL WORLD (2016). Oil world statistics. http:// www.oilworld.biz / app.php?ista $=3 \mathrm{e} 29384 \mathrm{f} 7 \mathrm{~d} 8 \mathrm{~b} 6 \mathrm{ed}$ 120a26459abe5fd4e.

SCHMID, H P (1997). Experimental design for flux measurements: matching scales of observations and fluxes. Agric. For. Meteorol., 87: 179-200.

STOY, P C; MAUDER, M; FOKEN, T; MARCOLLA, B; BOEGH, E; IBROM, A; ARAIN, M A; ARNETH, A L ; AURELA, M; BERNHOFER, C; CESCATTI, A; DELLWIK, E; DUCE, P; GIANELLE, D; VAN GORSEL, E; KIELY, G; KNOHL, A; MARGOLIS, H; MCCAUGHEY, H; MERBOLD, L; MONTAGNANI, L; PAPALE, D; REICHSTEIN, M; SAUNDERS, M; SERRANO-ORTIZ, P; SOTTOCORNOLA, M; SPANO, D; VACCARI, F and VARLAGIN, A (2013). A data-driven analysis of energy balance closure across FLUXNET research sites: The role of landscape scale heterogeneity. Agric For Meteorol., 171-172: 137-152.

SUNARYATHY, P I; SUHASMAN; KANNIAH, K D and TAN, K P (2015). Estimating aboveground biomass of oil palm trees by using the destructive method. World J. Agricultural Research, 3(1): 17-19.

VICKERS, D and MAHRT, L (1997). Quality control and flux sampling problems for tower and aircraft data. J. Atmos. Oceanic Technol., 14: 512-526.

WILSON, K; GOLDSTEIN, A; FALGE, E; AUBINET, M; BALDOCCHI, D; BERBIGIER, P; BERNHOFER, C; CEULEMANS, R; DOLMAN, H; FIELD, C; GRELLE, A; IBROM, A; LAW, B E; KOWALSKI, A; MEYERS, T; MONCRIEFF, J; MONSON, R; OECHEL, W; TENHUNEN, J; VALENTINI, R and VERMA, S (2002). Energy balance closure at FLUXNET sites. Agricultural and Forest Meteorology, 113: 223-243.

WOHLFAHRT, G; HAMMERLE, A; NIEDRIST, G; SCHOLZ, K; TOMELLERI, E and ZHAO, P (2016). On the energy balance closure and net radiation in complex terrain. Agricultural and Forest Meteorology, 226: 37-49. 